\title{
İŞ YAŞAMINDA BİR RİSK: MOBBİNG ÜZERİNE MİNÖR BİR İNCELEME
}

\author{
(Derya ÖZALP YILDIZ,derya.ozalp@hotmail.com)
}

\section{ÖZET}

\author{
(Doç. Dr.Abdulkadir DEVELİ, a.kadirdeveli@yahoo.com)
}

$\mathrm{Bu}$ makalede, mobingin iş yaşamında bir risk olarak çalışanlar üzerindeki etkilerini incelemek amaçlanmıştır. Araştırma nitel araştırma yöntemlerinden mülakat tekniği ile yapılmıştır. Araştırmanın çalışma grubunda çalışma yaşamının bir bölümünde mobbinge maruz kalmış 7 çalsşan yer almaktadır. Datalar çözümlenirken betimsel analiz tekniğinden yararlanılmıştır. Datalar daha önceden oluşturulmuş temalara uygun şekilde düzene konulmuş, ardından tematik çerçeveye uygun olacak şekilde tablolara işlenmiştir. Tablolar sayesinde kategoriler daha anlaşılır kılınmış, kategoriler arasında mukayese yapılması ve yorumlanması daha kolay olmuştur. Veriler, mobbingin iş yaşamında yaygın bir olgu olduğunu, bireysel, ailevi ve sosyal ilişkileri olumsuz etkilediğini, bunun yanında beden ve ruh sağlığını da olumsuz etkileyerek iş veriminde kayıplara yol açtığını açık şekilde ortaya koymuştur.

Anahtar Kelimeler: Mobbing, mobbing türleri, işyerinde mobbing.

\section{A RISK IN BUSINESS LIFE: A MINOR REVIEW ON MOBBING}

\begin{abstract}
This article aims to examine the effects of mobing on employees as a risk in business life. The research was conducted by interview technique from qualitative research methods. The study group includes 7 employees who have been exposed to mobbing in part of their working life. The visual analysis technique was used when analyzing the data. The data were sorted according to the previously created themes, then processed into tables to fit the thematic frame. Thanks to the tables, categories have been made more understandable, making it easier to compare and interpret between categories. The data clearly revealed that mobbing is a common phenomenon in business life, negatively affecting individual, familial and social relationships, as well as negatively affecting body and mental health, leading to loss in the work efficiency.
\end{abstract}

Keywords: Mobbing, mobbing types, mobbing in the workplace.

\section{GíRiş}

Mobbing, son ylllarda her sektörde görülmeye ve gittikçe dikkat çeken bir konu haline gelmeye başlamıştır. Mobbing çalışma hayatında çok rastlanan istendik olmayan sosyal ve psikolojik davranışları içermektedir. Mobbinge uğrayan kişiler, psikolojik olarak mutlu olmadıkları, mutsuz ve agresif bir atmosferde işlerine devam etmektedirler. Mobbing çalışanların motivasyonlarını düşürmekte, beden ve ruh sağlı̆̆ıı tehdit etmektedir. Dahası, zamanla iş performansını da negatif yönde etkilemekte ve kaçınılmaz şekilde iş kayıplarına sebebiyet vermektedir.

Literatür incelendiğinde "Mobbing kavramının, İngilizce ' $m o b$ ' kökünden geldiği, ' $m o b$ ' sözcüğünün, aşırı şiddetle ilişkili ve ‘yasaya uygun olmayan’ kalabalık anlamında kullanıldığı görülmektedir. Sözcük Latince 'mobile vulgus'dan türemiştir. İş yaşamında maddi manevi çok büyük zarara yol açan duygusal taciz, ancak yakın geçmişte başlı başına bir olgu olarak 
tanımlanmıştır ve Kuzey Amerika'dan Avrupa ülkelerine, oradan Japonya’ya kabul gören bir isme kavuşmuştur” (Komisyon Raporu, 2011:5)

Mobbing, kavram olarak öncelikle Amerika ve Avrupa'da ele alınan kavramlardan biri olmuştur. Türkiye'de de s1k sık duyduğumuz ve karşılaştığımız konulardan birisidir. Psikolojik yıldırma, psikolojik şiddet, baskı, kuşatma, taciz, rahatsız etme veya sıkıntı verme gibi anlamlara gelmektedir(Atman, 2012:157).

“Mobbing olgusu ilk kez 1960 yılında Avusturyalı bilim insanı Konrad Lorenz'in dikkatini çekmiş, aynı sürüden olmayan diğer hayvanlara karşı sürünün sergilediği sert ve kaba davranışlar olarak tarif etmiştir. Lorenz, mobbingden bahsederken, kurbanı mutsuz eden, dışlayıcı duygular içinde bırakan ve hatta ölümü düşünmesine neden olan rahatsız edici davranışları vurgulamak için kullanmıştır”(Yücetürk, 2005:98).

“Konrad Lorenz'den sonra aynı terimi İsveçli doktor Peter-Paul Heinemann çocuklardan kurulu bir grubun yalnız bir çocuğa tavır alıp zarar vermesini tanımlamak için kullanmıştır”, (Komisyon Raporu, 2011:5).

1984 yılında endüstri psikologu Heinz Leymann ise mobbing kavramını "Bullying” kavramı ile açıklamıştır. Zaman içinde "Bullying” kavramı genellikle "okul hayatındaki zorbalık” olarak ifade edilirken, mobing “iş dünyasındaki baskıyı, psikolojik tacizi” tarif etmek için kullanılmıştır.

Leymann (1996:166-168) bu kavramı öncelikle iş yeri terörü olarak ifade etmiştir. Leymann’a (1996:168) göre; “iş yaşamında mobbing, bir veya birden fazla personel tarafindan, sürekli ve sistematik olarak özellikle bir kişiye karşı yapılan ve bu kişiyi çaresiz, savunmasız bir duruma iten ahlak dışı ve süreklilik arz eden olumsuz eylemlerdir.

Çetin (2015:2)mobbingi, bir kişinin, grubun veya işverenin, diğer kişi veya gruba karşı, kişilerin duygusal anlamda yıpratılması, ruh sağlı̆̆ının bozulması, psikolojik ve patolojik bozukluklara neden olabilen, çalışanlar veya işveren tarafından bilinçli ve devamlı olarak yapılan davranışların tümü olarak tarif etmiştir.

Mobbing üzerine çalışmaları bulunan Field ise bu kavramı, "hedef kişilerin özgüvenlerine ve özsaygılarına yönelik sürekli ve acımasız bir saldırı olarak tanımlamıştır” (Field, 1996:33).

“Günümüzde mobbing kavramı, sistemli bir şekilde, süreklilik arzeden bir sıklıkta, çalışanı sindirme maksadı ile kişinin özgüvenine uygulanan psikolojik ve hatta fiziksel saldırgan davranışı ifade etmek için kullanılmaktadır” (Atman, 2012:160). Başka bir deyişle, "iş yerinde bir kişinin 
veya bir grubun, istenmeyen kişi olarak ilan ettikleri bir kişiyi dışlayarak, sözlü ya da fiziksel tacizde bulunarak mutlak itaate zorlaması, yıldırması ve bezdirmesi olarak tanımlanmaktadır" (Komisyon Raporu: 2011:6).

Mobbing kavramı “Türkçe'ye ilk olarak yabancı literatürde olduğu gibi 'mobbing' şeklinde girmiş olup, mobbing üzerine araştırma yapanlar, genel anlamda Türkçe karşıllk olarak 'işyerinde psikolojik taciz', 'psikoşiddet', 'iş yerinde psikolojik terör', 'işyerinde psikolojik şiddet', 'iş yerinde duygusal taciz', 'iş yerinde manevi taciz', 'iş yerinde zorbalık', iş yerinde yıldırmaya yönelik psikolojik saldırı' gibi kavramları kullanmışlardır. Dolayısıyla kavramın tek bir sözcük yerine birkaç sözcükle ifade edilmesi daha doğru gibi gözükmektedir” (Bulut ve Göktürk, 2012:54).

Mobbing kavramının geçmişi uzun yıllara dayansa da ülkemizde farkındalık son yıllarda artmaya başlamıştır. Türk hukukunda henüz doğrudan mobbing ile ilgili düzenlemeler yer almamış olsa da Anayasa, İş Kanunu, Medeni Kanun, Borçlar Kanunu ve Ceza Kanunu'nda mobbinge maruz kalan kişileri korumak adına bazı maddeler yer almaktadır. 657 Sayılı Devlet Memurları Kanunu'nda da alt kademede çalışan ve üst kademede çalışanların görev tanımları açık ve net olarak belirlenmiştir. 10. maddede üst yöneticilerin yetki ve görevleri belirtilerek, astlarına eşit hak ve adaletli davranarak ve yöneticilik yetkisini kanun, tüzük ve yönetmeliklerde açıklanan kurallar içinde yapılması gerektiği belirtilmiştir. (657 DMK, madde 10).

"Uluslararası Çalışma Örgütü'nün (ILO) yapmış olduğu araştırmada Avrupa'da iş hayatında ortalama 12.000.000 kişinin mobbing yaşadığ tespit edilmiştir" (Martino, 2003: 22). Matthiesen ve Einarsen (2004) Avrupa'da mobbingin \%11 düzeyinde olduğunu ifade etmektedir. İniltere'de yapılmış bir araştırmaya katılan çalışanların \%53 'ü kariyerleri boyunca en az bir kere mobbing davranışına maruz kaldığını ifade ederken, \%78'i ise, bu tür davranışlara tanık olduğunu kaydetmiştir (Chappell ve DiMartino, 1998: 4). ABD'de 1.158 üniversite çalışanı ile yapılan araştırmada katılımcıların \%55'inin psikolojik taciz davranışlarına maruz kaldığg, \%2'sinin ise mă̆dur olduğu belirlenmiştir (Komisyon Raporu, 2011: 18).

“Ülkemizde bu konuyla ilgili yapılan çalışma sayısı kısıtlı olmakla beraber, Bursa'da sağlık, eğitim ve güvenlik sektöründe yapılan bir çalışmada, 944 kişinin \%55'inin son bir yıl içinde mobbingle karşılaştığı, \%47'sinin ise tanık olduğu belirlenmiştir. Yine Aksaray-Yalova- Esenköy eğitim merkezlerinde çalışan 315 ilkokul öğretmenin \%50'sinin işyerinde mobbingle karşılaştığ saptanmıştır. İstanbul'da 505 hemşireyi kapsayan bir çalışmada da hemşirelerin \%86'sının mobbinge maruz kaldığı kaydedilmiştir. Human Resources Management, 2008 yılında Türkiye'deki mobbing vakalarını araştırmak amacıyla "yenibiris.com” üzerinden bir anket düzenlemiş, söz 
konusu ankete 100 kişi katılmış, katılanların \%56'sını erkekler, \%44'ünü ise kadınlar oluşturmuştur. $\mathrm{Bu}$ çalışmada iş hayatında mobbingle karşılaştıklarını söyleyenlerin oranı \%81 olarak belirlenmiştir. Ankete katılanların \%70’i, bu davranışı, yöneticisi konumunda olan kişi ya da kişilerden, \%25'i aynı seviyedeki çalışma arkadaşları tarafından gördüklerini ifade etmişlerdir. Anket sonuçlarına göre; mobing vakalarının, \%27'si istifa, \%25'i bilmezden gelip işe devam etme \%18'i işten çıkarılma, \%17'si ise bu durumu üst yönetim ya da insan kaynakları yetkilisine iletme ile sonuçlandırmıştır. Geri kalan küçük bir oran ise farklı sonuçlara ulaşmış; örneğin üst yönetim ile konuşup değişiklik olmayınca istifa etmiş, durumu ilk amirleriyle paylaşmış ya da benzer bir tavırla karş1lık vermişlerdir” (Komisyon Raporu, 2011: 17; Tınaz ve Karatuna, 2010: 43-44; Atman, 2012: 161-162).

Sonuç olarak mobbingin günümüz sanayi toplumları için yaygın bir sorun alanı olduğu anlaşılmaktadır. Veriler, mobbingin en hızlı artan işyeri şiddet olgusu olduğunu göstermektedir.

Mobbing davranışıla karşılaşan çalışanların iş yaşamındaki başarısı ve verimliliği düşmekte, sosyal hayatta yaşamı olumsuz etkilenmekte, fiziksel, sosyal ve ruhsal açıdan yaşam kalitesi düşmekte, hatta çalışanın işten ayrılmasına, intihar etmesine kadar gidebilmekte, örgütsel olarak ise örgüt barış ve huzurunun bozulmasına sebep olup, örgütsel verimliliğe ve dolayısıyla ülke ekonomisine olumsuz etkiye sebep olduğunu belirtmek gerekir. "Leymann'ın 1990 yılında yapmış olduğu çalışmalara dayanan verilere göre bir mağdurun yıllık örgütsel maliyeti 30.000 ile 100.000 USD arasında değişmektedir” (Atman, 2012:169). “Avustralya Griffith Üniversitesi Yönetim Bölümünün hazırlamış olduğu rapora göre Avustralya'da mobbing işverenlere yıllık 36 milyar dolara mal olmaktadir" (Komisyon, 2011:19).

$\mathrm{Bu}$ temelde mobbingin 4 noktada maliyeti olduğu ifade edilmektedir: "I-Endüstri ve vergi mükellefleri açısından 2- İşverenler açısından 3- Mobbing (İşyerinde Psikolojik Taciz) mă̆duru ve ailesi açısından 4- Mahkeme ve avukat masrafları açısından” (web 1).

Sonuç olarak mobbingin evrensel bir olgu olduğu görülmekte, bireysel, toplumsal ve iktisadi hasarlara yol açan olumsuz bir süreç olduğu açık şekilde anlaşılmaktadır.

\section{MOBBING ÇEŞITLERI}

Çalışanlar mobbing davranışları ile kamu ya da özel sektör ayırt etmeksizin tüm işyerlerinde karşı karşıya kalmaktadırlar. "Çalışma hayatında mobbing süreçleri, dikey (hiyerarşik), yatay ve düşey mobbing olmak üzere üç farklı şekilde görülmektedir”(Atman, 2012:162). 


\subsection{Dikey (Hiyerarşik)Mobbing}

Çalışanın yöneticiye psikolojik şiddet uygulamasıdır. Nadir görülen bir durumdur. Örneğin, çalışanların yöneticiyi kabullenememesi, eski yöneticiye duyulan bağlılık, kıskançlık gibi (Komisyon Raporu, 2011:10).

\subsection{Yatay Mobbing}

"İşyerinde mobbingin fail ve failleri mağdur ile benzer görevlerde ve benzer olanaklara sahip, aynı konumdaki iş arkadaşlarıdır. Örneğin; eşit koşullar içinde bulunan çalışanların çekememezliği, rekabet, çıkar çatışması, kişisel hoşnutsuzluklar gibi”(Atman, 2012:163).

İşyerlerinde yaşanılan kişisel çatışmalar, başarılı olduğunu düşündükleri çalışanların ilerleyen zamanlarda kendilerine rakip olabileceği düşüncesi, objektif olmayan görüşler ve önyargilar yatay mobbinge yol açabilmektedir (Güngör, 2008: 65).

\subsection{Düşey Mobbing}

Üst konumda yer alanların astlarına yönelik olarak gerçekleştirdikleri mobbing vakalarıdır. Üstlerin sahip oldukları kurumsal gücü, astlarını ezerek, onları kurumun dışına iterek kullanmasıdır (Atman, 2012:162).

Mobbing eylemleri incelendiğinde tesadüfler bir yana, belli stabil aşamalar barındırarak ilerleyen bir süreç olduğu anlaşılmaktadır. Endüstri psikologu Leymann'dan aktaran Tetik (2010:83-84), mobbingin beş aşamada cereyan ettiğini tespit etmiştir. Bunlar sırasıyla aşağıdaki gibidir.

“ Çatışma Aşaması: Bu aşama, daha çok bir çatışmanın tetiklemesiyle oluşacă̆l gibi var olan bir çatışmanın alevlendirilmesi ve kışkırtılmasıyla da ortaya çıkabilmektedir.

Saldırgan Eylem Aşaması: Mobbing sürecinde ortaya çıkan davranışların tümünün, kişiyi işyerinden uzaklaştırmak amacıyla yapılan saldırı girişimli davranışlar olduğu söylenemez. Bununla birlikte taciz edici davranışlar, hemen hemen her gün ve uzun bir süre düşmanca bir amaçla devam ederse; normal günlük iletişim içinde ortaya çıkan davranışlar olarak kabul edilebilir. Bu davranışlar, zaman içerisinde şekil değiştirerek kişiyi, grup içerisinde yalnız bırakıp cezalandırmaya yönelik saldırgan eylemlere dönüşebilir. Saldırgan eylemlerin ve psikolojik saldırıların başlaması, mobbing dinamiklerinin harekete seçtiğini gösterir.

Yönetimin Devreye Girmesi Aşaması: Yönetim sürecin ikinci aşamasında doğrudan doğruya yer almamışsa da, bir önceki aşamada ortaya çıkan duruma önyargıyla yaklaşabilir. Olayları yanlış yargılayıp suçu, yalnız bırakılan mobbing mağdurunda bulma ve problemi başından atma eğilimini benimseyebilir. Bu noktada yönetim, negatif döngü içindeki yerini almış olur. 
Bireyin çalışma arkadaşları ve yönetim, bireyin işi ile ilgili temel nitelikleri yerine, kişisel özellikleri ile ilgili hatalar bulma ve kişiyi damgalamaya yönelik açıllımlar üretmeye başlarlar.

Yanlış Yakıştırmalarla veya Tanılarla Damgalama: Mobbing mağduru; mobbing nedeniyle karşılaştı̆̆ sorunları çözebilmek için tıbbi yardım almaya çalıştı̆̆ında, işyerindeki diğer çalışanlarında bu durumdan haberdar olmalarıla mobbing mağduru hakkında yanlış yorumlar yapılmaya başlanır. Böylece kişi hak etmediği halde "zor insan, paronayak kişilik veya akıl hatası" olarak damgalanır. Buna yönetimin yargısıla birlikte, mobbing olgusu hakkında yeteri kadar bilgisi olmayan sağlık uzmanlarının yanlış tanıları eklenirse, mobbingde negatif döngü hızlanır”.

İşten Çıkarılma Aşaması: En son aşamada, mobbing saldırılarına maruz kalan kişi ya emekli olarak ya da işten çıkarılarak iş hayatından uzaklaşır”.

Mobbing aşamalarında özne olarak yer alan mobbingcilere ilişkin ortak bir tasnif yapılmıştır. Tezcan ve arkadaşlarından aktaran Tetik'e (2010: 84-85) göre en sık rastlanan mobbingci bireyler 9 farklı kategoride sınıflandırılmıştır.

> “Fesat mobbingci: Yeni kötülükler arayan bir kişidir. Iftiralarla başkalarını yaralamaya çalışır.

> Hiddetli mobbingci: Karakter özelliği nedeniyle fevridir. Sürekli bă̆ırma, beddua etme modundadır. Sinir ve huysuzluk krizleriyle işyerini çekilmez yapar. Kişilerin duygu ve düşüncelerini aşağllarlar.

> Megaloman mobbingci: Kendisini herkesten üstün görür. Kendine olan güvensizliği başkalarına karşı kıskançlık, nefret ve saldırganlık olarak yansır. Bu kişiye göre tüm kaynakların kontrolü kendisindedir. Uydurduğu kurallara herkes uymak zorundadır.

> Sadist mobbingci: Başkalarını köşeye sıkıştırmaktan, mahvetmekten büyük zevk duyar. Bu kişi 'sapkın narsist' olarak da tanımlanabilir. Hiyerarşik kademelerde yükselebilmek için her yola başvurabilir.

> Dalkavuk mobbingci: Yöneticilerinin gözüne girmek için yaranma halindedir ve her şeyi yapmaya hazırdır. Yöneticinin dalkavuğu gibidir.

> Zorba mobbingci: Sadist mobbingciye benzer. Son derece acımasiz ve zalimdir. Insanlara köle gibi davranır.

> Korkak mobbingci: Bir başkasının daha başarılı olacă̆l, yükseleceğini düşünerek paniğe kapılır. Kendini korumak için mobbing uygulamayı seçer.

> Eleş̧irici mobbingci: Başkalarının yaptı̆̆ı işten hiç memnun kalmaz, sürekli eleş̧tirir. Issyerinde memnuniyetsizlik ve gerginlik dolu bir iklimin oluşmasına sebebiyet verir. 
Hayal kırıklı̆̆ına uğramış mobbingci: Çalışma yaşamı dışında yaşanan tüm olumsuz duygular, tüm yeterliksizlikler veya kötü deneyimler, bu mobbingciler tarafindan işyerinde başkalarına yansıtılır. Daima başkalarına karşı kıskançlık ve haset duyguları mevcuttur”.

\section{YÖNTEM}

Yöntem amaca ulaşmak için başvurulan hareket ve bakış açısını ifade eden bir plandır. Araştırmada bilimsel sonuçlara ulaşabilmek için ilk aşamadan son aşamaya kadar benimsenen yönteme uygun davranılması gerekir.Her araştırmanın bir yöntemi vardır. Bu araştırmanın yöntemi nitel yöntemdir. Nitel araştırma yöntemi; niçin, nasıl, ne şekilde gibi sorulara cevap bulmak amac1 ile kullanılır(Creswell, 2017:190). Araştırma yöntemine uygun olarak mülakat tekniği kullanılmıştır.

Mülakat tekniği sosyal bilimlerde oldukça sık başvurulan bir veri toplama tekniğidir. Mülakat bireylerle karşılıklı konuşma yolu ile veri toplama tekniğidir. $\mathrm{Bu}$ kapsamda 7 görüşmeci ile derinlemesine mülakatlar gerçekleştirilmiştir. Bütün katılımcılara araştırmanın amacından açıkça söz edilmiş, araştırmaya katılmak istemeyenler araştırma dışında bırakılmış, son aşamada mülakatı kabul eden katılımcıların gönüllüğüne dayanılarak araştırma gerçekleştirilmiştir.

Mülakatlar sonucu katılımcılardan elde edilen datalar araştırmanın amacı doğrultusunda betimsel analiz ile değerlendirilmiştir. Betimsel analiz yapılırken ham datalar daha önceden oluşturulmuş temalara uygun şekilde düzene konulmuş, ardından tematik çerçeveye uygun olacak şekilde tablolara işlenmiştir. Tablolar sayesinde kategoriler daha anlaşılır kılınmış, kategoriler arasında mukayese yapılması ve yorumlanması daha kolay olmuştur. Bununla birlikte datalar temalarına göre tablolara yerleştirilirken araştırma amacının dışında kalan kimi veriler dışarıda bırakılmıştır.Katılımcıların isimleri ve çalıştıkları kurumlar gizli tutulmuştur. Katılımcıları birbirinden ayırt edebilmek için her birine Mağdur 1, Mağdur 2 gibi isimler verilmiştir.

Katılımcıların cinsiyet, yaş, eğitim, medeni durum, statü, tecrübelerine ilişkin bilgiler aşağıdaki gibidir:

Tablo 1: Katılımcılara İlişkin Demografik Bilgi Tablosu

\begin{tabular}{|l|l|l|l|l|l|l|}
\hline İsim & Cinsiyet & Yaş & Eğitim & $\begin{array}{l}\text { Medeni } \\
\text { Durum }\end{array}$ & Statü & Tecrübe \\
\hline
\end{tabular}


Uluslararası Anadolu Sosyal Bilimler Dergisi

... (akademik, hakemli, indexli, uluslararası dergi)

\begin{tabular}{|l|l|l|l|l|l|l|}
\hline Mağdur 1 & Erkek & 34 & Lisans & Evli & Memur & 6 yıl \\
\hline Mağdur 2 & Erkek & 32 & Lisans & Evli & Memur & 5 yıl \\
\hline Mağdur 3 & Kadın & 33 & $\begin{array}{l}\text { Yüksek } \\
\text { Lisans }\end{array}$ & Evli & Memur & 10 yıl \\
\hline Mağdur 4 & Erkek & 36 & Lisans & Bekar & Satış & 2 y1l \\
& & & & & Sorumlusu & \\
\hline Mağdur 5 & Kadın & 43 & Yüksek & Bekar & Yönetici & 10 yıl \\
& & & Lisans & & Asistanı & \\
\hline Mağdur 6 & Kadın & 44 & Yüksek & Evli & Muhasebe & 10 yıl \\
& & & Lisans & & Uzmanı & \\
\hline Mağdur 7 & Erkek & 45 & Lisans & Evli & Doktor & 15 y1l \\
\hline
\end{tabular}

\section{BULGULAR}

\subsection{Katılımcıların Hangi Davranışları Mobbing Olarak Gördüklerine İlişsin Bulgular}

Katılımcıların mobbing davranışını tanımlama ile ilgili görüşleri aşağıdaki gibidir.

Tablo 2: Katılımcıların Hangi Davranışları Mobbing Olarak Gördüklerine İlişkin Bulgular ve Yorumları

\begin{tabular}{|l|c|c|l|}
\hline Katılımcılar & $\begin{array}{l}\text { Yöneticiler } \\
\text { veya çalışma } \\
\text { arkadaşları } \\
\text { tarafından } \\
\text { uygulanan } \\
\text { olumsuz söz } \\
\text { ve } \\
\text { davranışlar }\end{array}$ & $\begin{array}{l}\text { Psikolojik } \\
\text { baskı }\end{array}$ & $\begin{array}{l}\text { Sistematik } \\
\text { yıldırma } \\
\text { çabaları }\end{array}$ \\
\hline Mağdur 1 & $\mathrm{X}$ & $\mathrm{X}$ & $\mathrm{X}$ \\
\hline Mağdur 2 & $\mathrm{X}$ & $\mathrm{X}$ & $\mathrm{X}$ \\
\hline Mağdur 3 & $\mathrm{X}$ & $\mathrm{X}$ & $\mathrm{X}$ \\
\hline Mağdur 4 & $\mathrm{X}$ & $\mathrm{X}$ & $\mathrm{X}$ \\
\hline Mağdur 5 & $\mathrm{X}$ & $\mathrm{X}$ & $\mathrm{X}$ \\
\hline Mağdur 6 & $\mathrm{X}$ & $\mathrm{X}$ & $\mathrm{X}$ \\
\hline Mağdur 7 & $\mathrm{X}$ & $\mathrm{X}$ & $\mathrm{X}$ \\
\hline
\end{tabular}


Mülakatlardan elde edilen verilere göre katılımcıların mobbingi olumsuz söz ve davranışlar, psikolojik baskı ve sistematik yıldırma çabaları olarak gördükleri görülmüş ve anlaşılmıştır. Tüm katılımcıların yapılan mülakata verdiği yanıtlarda "psikolojik baskı ve yıldırma" ifadelerini sıklıkla kullandıkları dikkati çekmiştir. Örneğin Mağdur 2 mobbingi "çalışanı işten çıkarmak için yapılan zorlama ve bask1", Mağdur 3 "İ̧ yerinde sözlü olarak üstünlük kurma ve bask1 ve yıldırma yapma”, Mağdur 4 "çalışanların maruz bırakıldığı olumsuz davranışlar". Mağdur 4 "kişiyi işten çıkarmak için yapılan baskı yıldırma politikası”, Mağdur 7 "Bir işyerinde bir grubun tacizine, zorbalığına maruz kalmak, sindirilmeye çalışılmak, düşmanca tavırlara maruz kalmak" şeklinde tarif etmişlerdir. Tüm mağdurların kendilerine uygulanan mobbing olgusu ile ilgili farkındalık sahibi oldukları anlaşılmaktadır.

\subsection{Katılımcıların Çalışma Yaşamında Maruz Kaldığı Mobbing Davranışlarına İlişkin}

\section{Bulgular}

Yapılan mülakatlarda katılımcıların işyerinde birbirinden farklı mobbing türlerine maruz kaldıkları görülmüştür. Bu konuda katılımcıların görüşleri aşağıdaki gibidir.

Tablo 3: Katılımcıların Çalışma Yaşamında Maruz Kaldığı Mobbing Davranışlarına İlişkin Bulgular ve Yorumları

\begin{tabular}{|l|c|c|c|c|}
\hline Katılımcılar & Dışlanma & $\begin{array}{l}\text { Baskı, } \\
\text { yıldırma }\end{array}$ & Aşağılanma & $\begin{array}{l}\text { Maddi } \\
\text { ve } \\
\text { manevi } \\
\text { zarara } \\
\text { uğrama }\end{array}$ \\
\hline Mağdur 1 & $\mathrm{X}$ & $\mathrm{X}$ & & $\mathrm{X}$ \\
\hline Mağdur 2 & $\mathrm{X}$ & $\mathrm{X}$ & $\mathrm{X}$ & $\mathrm{X}$ \\
\hline Mağdur 3 & $\mathrm{X}$ & $\mathrm{X}$ & $\mathrm{X}$ & $\mathrm{X}$ \\
\hline Mağdur 4 & $\mathrm{X}$ & $\mathrm{X}$ & & $\mathrm{X}$ \\
\hline Mağdur 5 & $\mathrm{X}$ & $\mathrm{X}$ & $\mathrm{X}$ & $\mathrm{X}$ \\
\hline Mağdur 6 & $\mathrm{X}$ & $\mathrm{X}$ & & $\mathrm{X}$ \\
\hline Mağdur 7 & $\mathrm{X}$ & $\mathrm{X}$ & & $\mathrm{X}$ \\
\hline
\end{tabular}


Verilen yanıtlar değerlendirildiğinde, mağdurların tamamının mobing sonucunda dışlandığ1, baskı/yıldırmaya maruz kaldığı, maddi/ manevi zarara uğradıkları açık şekilde anlaşılmaktadır. Mağdur 2, Mağdur 3, Mağdur 5' in bunların yanında aşağılanmaya maruz kaldıkları görülmektedir. Mağdur 1 "İş ortamında dışlanma, itibarsızlaştırmaya maruz kaldığını”, Mağdur 2 “işverenin görev dağılımı yaparken kendisinin bilgi ve yeteneklerini dışlayarak alakasız işler verdiğini”, Mağdur 5 "yönetici tarafından niteliklerinin altında iş verildiğini ve bu işleri yapmaya zorlandığını", Mağdur 6 "dışlanma, yalnız bırakılma, işle ilgili bilgilerin paylaşılmaması, söylediklerine karşı çıkılması, eğitim ve niteliklerinin altında görevler verilmesi” ş̧eklinde ifadelerde bulunmuşlardır. Bulgulara göre işyerlerinde mobbingin genellikle birden fazla şekli ile çalışanlara uygulandığ sonucu çıkmaktadır. Bir davranışın mobbing olarak nitelendirilmesi için davranışların sistemli ve düzenli bir şekilde 6 ay süreyle gerçekleşmesi gerektiği hatırlandığında mobbinge maruz kalan kişilerin gerek işyerinde gerek iş yeri dışındaki yaşamlarında genel zarar ve hasarlar gördükleri açık şekilde ifade edilebilir.

\subsection{Katılımcıların Kim Tarafından Mobbinge Maruz Kaldıklarına İlişkin Bulgular}

Nerede bir mobbing var ise orada mobbingi yapan biri bulunmaktadır. Yapılan mülakatlarda katılımcıların işyerinde kim tarafından mobbinge maruz kaldığına ilişkin görüşleri aşağıdaki gibidir.

\section{Tablo 4: Katılımcıların Kim Tarafından Mobbinge Maruz Kaldıklarına İlişkin Bulgular ve Yorumları}

\begin{tabular}{|l|c|c|c|c|c|}
\hline Katılımcılar & $\begin{array}{c}\text { İş } \\
\text { Arkadaşları }\end{array}$ & $\begin{array}{c}\text { Baş } \\
\text { Yönetici }\end{array}$ & $\begin{array}{c}\text { Yönetici } \\
\text { Yardımcısı }\end{array}$ & İşveren & Hepsi \\
\hline Mağdur 1 & & & & $\mathrm{X}$ & \\
\hline Mağdur 2 & & $\mathrm{X}$ & $\mathrm{X}$ & & \\
\hline Mağdur 3 & $\mathrm{X}$ & $\mathrm{X}$ & & & \\
\hline Mağdur 4 & $\mathrm{X}$ & $\mathrm{X}$ & & $\mathrm{X}$ & \\
\hline Mağdur 5 & & $\mathrm{X}$ & $\mathrm{X}$ & & \\
\hline Mağdur 6 & $\mathrm{X}$ & $\mathrm{X}$ & & & \\
\hline Mağdur 7 & $\mathrm{X}$ & & $\mathrm{X}$ & & \\
\hline
\end{tabular}

Tablo 4 incelendiğinde mobbing uygulayan kişilerin kişiden kişiye farklılık gösterdiği görülmektedir. Tabloya göre mağdurların daha çok ekip arkadaşları ve yöneticiler tarafından 
mobbinge maruz kaldığı anlaşılmaktadır. Yönetici yardımcıları onları izlerken, işverenlerin daha az mobbing uyguladığı görülmektedir. Tablodan çıkan diğer bir sonuç da mağdur ile mobbing uygulayan arasında statï eşitsizliğinin söz konusu olduğu anlaşılmaktadır.

\subsection{Katılımcıların Mobbingden Etkilenme Biçimlerine İlişkin Bulgular}

\section{Tablo 5: Katılımcıların Mobbingden Etkilenme Biçimlerine İlişkin Bulgular ve Yorumları}

\begin{tabular}{|c|c|c|c|c|}
\hline Katılımcılar & $\begin{array}{c}\text { Aile } \\
\text { Hayatında } \\
\text { Mutsuz }\end{array}$ & $\begin{array}{l}\text { Olumsuz } \\
\text { Düşünce }\end{array}$ & $\begin{array}{c}\text { Sinirli ve } \\
\text { Agresif } \\
\text { Davranışlar }\end{array}$ & $\begin{array}{c}\text { Bedensel } \\
\text { Acı } \\
\text { (Stres, } \\
\text { Mide, } \\
\text { Baş } \\
\text { Ağrısı } \\
\text { vb.) }\end{array}$ \\
\hline Mağdur 1 & $\mathrm{X}$ & $\mathrm{X}$ & & \\
\hline Mağdur 2 & & & $\mathrm{X}$ & \\
\hline Mağdur 3 & $\bar{X}$ & $\bar{X}$ & $\mathrm{X}$ & \\
\hline Mağdur 4 & & & $\mathrm{X}$ & \\
\hline Mağdur 5 & $\mathrm{X}$ & $\mathrm{X}$ & $\mathrm{X}$ & $\mathrm{X}$ \\
\hline Mağdur 6 & $\bar{X}$ & $\bar{X}$ & $X$ & $\mathrm{X}$ \\
\hline Mağdur 7 & $\bar{X}$ & $\mathrm{X}$ & $X$ & $\mathrm{X}$ \\
\hline
\end{tabular}

Verilen yanıtlara bakıldığında mobbing sonrasında Mağdur 1, Mağdur 3, Mağdur 5, Mağdur 6, Mağdur 7'nin aile hayatında mutsuz ve olumsuz düşüncelere kapıldı̆̆ı, Mağdur 2-3-4-5-6-7'nin sinirli ve agresifleştiği, Mağdur 5-6-7'nin yaşadıklarının yanı sıra bedensel acılarla (stres, mide, baş ağrısı vb.) da uğraştıkları anlaşılmaktadır. Örneğin Mağdur 4 mobbing sonrasında "gerek işyerinde gerekse işyeri dışında elinde olmadan sürekli sinirli ve agresif davranışlar sergilediğini, ağrı kesici ve kas gevşetici gibi ilaçlar kullandığını" dile getirmiştir. Mağdur 5, Mağdur 6 ve Mağdur 7 "sürekli stresli olduklarını, mide ve baş ağrıları çektiklerini, kendilerine karşı uygulanan bu olumsuz davranışların onları gergin ve sinirli yaptığını, bunun sonucunda istemeden de olsa aile bireylerini kırdıklarını, ani tepkiler verdiklerini, kendilerini mutsuz hissettikleri için sosyal çevreleriyle ve arkadaşlarıyla görüşmek istemediklerini” söylemiştir. Örneğin Mağdur 1 “işyerinde yaşadıklarımı aileme yansıtmamak için özel çaba sarfediyordum” derken, Mağdur 3 "aile hayatımı, özel hayatımı, ilişkilerimi etkiledi. Olumsuz düşünen birisi oldum" diye durumu özetlemiş, Mağdur 6 "Eve 


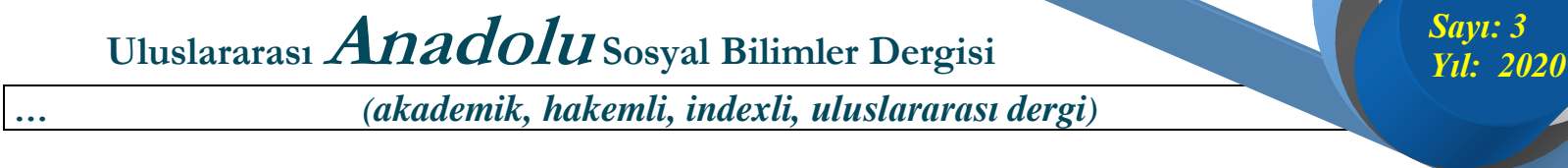

geldiğimde aileme ve eşime karşı sinirli oluyordum. Ağlayarak işyerindegeçirdiğim sıkıntıları anlatıyordum onlarıda üzüyordum.", diye ifade etmiş, Mağdur 7 ise "İş yerindeki bu huzursuzluk hem kendi iç dünyamda, hem arkadaş çevremde hem de aile hayatımda etkisini gösteriyor, huzursuz ve mutsuz hissediyordum. Haksızlığa uğramanın öfkesini yaşıyordum” şeklinde yaşadıklarını dile getirmiştir. Buna göre mağdurların psikolojik, bedensel ve sosyal yaşantılarında mobbing sürecinin tahrip edici olduğu ve bireyler üzerinde işyeri hayatından aile ve sosyal hayata kadar geniş bir alanda hasar bıraktığı açık şekilde ifade edilebilir.

\subsection{Katılımcıların Mobbing Uygulayıcılarının Davranışlarının Altında Yatan Sebeplere İlişkin Bulgular}

Yapılan mülakatlarda katılımcıların mobbing uygulayıcılarının davranışlarının altında yatan çeşitli sebepler olduğuna dair tespitleri bulunmaktadır. Bu konuda katılımcıların görüşleri aşağıdaki gibidir.

Tablo 6: Katılımcıların Mobbing Uygulayıcılarının Davranışlarının Altında Yatan Sebeplere İlişkin Bulgular ve Yorumları

\begin{tabular}{|l|c|c|c|c|c|}
\hline Katılımcılar & Mutsuz & $\begin{array}{l}\text { Organizasyon } \\
\text { Yapısı }\end{array}$ & Güvensizlik & Samimiyetsizlik & $\begin{array}{c}\text { Yönetim } \\
\text { Tarzı }\end{array}$ \\
\hline Mağdur 1 & $\mathrm{X}$ & & & & \\
\hline Mağdur 2 & & & $\mathrm{X}$ & & $\mathrm{X}$ \\
\hline Mağdur 3 & & $\mathrm{X}$ & & & $\mathrm{X}$ \\
\hline Mağdur 4 & & $\mathrm{X}$ & & & $\mathrm{X}$ \\
\hline Mağdur 5 & & & $\mathrm{X}$ & $\mathrm{X}$ & $\mathrm{X}$ \\
\hline Mağdur 6 & $\mathrm{X}$ & & $\mathrm{X}$ & $\mathrm{X}$ & $\mathrm{X}$ \\
\hline Mağdur 7 & & $\mathrm{X}$ & $\mathrm{X}$ & $\mathrm{X}$ & \\
\hline
\end{tabular}

Tablo 6 incelendiğinde mobbing uygulayıcılarının davranışlarının altında öne çıkan 5 neden buldukları anlaşılmıştır. Bunların başında işyerlerindeki "yönetim tarzı” gelmektedir. Mağdur 3-45-6-7 verdikleri yanıtlarda, yöneticilerin yönetim tarzının mobbing davranışlarında en büyük etken olduğunu ifade etmişlerdir. Mağdur 4 "firmanın içcinde bulunduğu sektörün de mobbing davranışında etkili olduğunu" dile getirmiş, "firmanın geleneksel aile yapısını sürdürdüğünden onların da bu duruma destek verdiklerini” belirtmiştir. Mağdur 1 ve Mağdur 6'nın ise “ mobbing uygulayanların temelde kendisiyle barışık olmayan, mutsuz insanlar” olduklarını, Mağdur 2-5-6-7 
“mobbingcilerin çalışanlara karşı güvensizlik duygularının” olduğunu, Mağdur 5-6-7’nin de "mobbingciler samimiyetten uzak kimseler" olduklarını ifade etmişlerdir.

\subsection{Katılımcıların Mobbing Sürecini Nasıl Yönettiklerine İlişkin Bulgular}

Mağdur her bireyin mobbing sürecine tepkisi farklı farklı olmaktadır. Bu tepkiler mobbing ile mücadele etmeden istifaya kadar geniş bir yelpaze sunmaktadır. Yapılan mülakatlarda katılımcıların mobbing sürecini nasıl yönettiklerine ilişkin bulgular aşağıdaki gibidir.

\section{Tablo 7: Katılımcıların Mobbing Sürecini Nasıl Yönettiklerine İlişkin Bulgular ve} Yorumları

\begin{tabular}{|l|c|c|c|c|}
\hline Katılımcılar & $\begin{array}{c}\text { Sessiz } \\
\text { Kalma }\end{array}$ & $\begin{array}{l}\text { Bağlı } \\
\text { Olduğu } \\
\text { Yönetici } \\
\text { ile } \\
\text { Konuş ma }\end{array}$ & İstifa & $\begin{array}{c}\text { Mücadele } \\
\text { Etme }\end{array}$ \\
\hline Mağdur 1 & & $\mathrm{X}$ & & \\
\hline Mağdur 2 & $\mathrm{X}$ & $\mathrm{X}$ & & \\
\hline Mağdur 3 & $\mathrm{X}$ & $\mathrm{X}$ & $\mathrm{X}$ \\
\hline Mağdur 4 & & $\mathrm{X}$ & $\mathrm{X}$ & \\
\hline Mağdur 5 & & $\mathrm{X}$ & & \\
\hline Mağdur 6 & $\mathrm{X}$ & $\mathrm{X}$ & & $\mathrm{X}$ \\
\hline Mağdur 7 & $\mathrm{X}$ & $\mathrm{X}$ & \\
\hline
\end{tabular}

Tablo 7'ye göre Mağdur 2, Mağdur 3, Mağdur 5 ve Mağdur 6'nın maruz kaldıkları mobbinge karşı sessiz kaldıkları görülmektedir. Katılımcılar "yöneticileriyle veya çalışma arkadaşları ile bu durumu konuşsalar bile yasal bir haklarının olmadığını öne sürerek durumun değişmeyeceğini düşündüklerini, işini kaybetmekten korktukları için sessiz kaldıklarını” ifade etmiş̧lerdir. Mağdur 1 “mobbing ile mücadele ettiğini, işyerinde bölüm değişikliği yaparak" kendince çözüm bulduğunu dile getirirken, Mağdur 3 "O insanları görmezden gelerek ve yok sayarak" şeklinde açılama yapmıştır.Mağdur 4 "kendisine verilen işlerin tamamını yaptığını, iş arkadaşlarına karşı hoşgörülü davrandığııı, olumsuz cümlelerden kaçındığını, işe kendini motive ederek mücadelesini sürdürdüğünü" dile getirmiştir. Mağdur 5 ise "yöneticisiyle konuştuğunu, diğer çalışma arkadaşlarını görmezden gelerek aralarına mesafe koyarak çalışmaya devam ettiğini, ama kendisine karşı yıldırma davranışının daha da arttığını ve istifaya zorlandığını, daha sonra da işten istifa etmeye mecbur bırakıldığını” dile getirirken, Mağdur 7 "Kişiliğimi, duruşumu koruyarak, dik durarak, 
güçlü görünerek, tehlikelere gardımı alarak ve insanlara mesafeli davranarak korunmaya çalışıyordum" şeklinde yaşadıklarını açıklamıştır.

\section{Sonuç}

Günümüzde mobbing, dil, din, irk fark etmeksizin tüm dünyada gerçekleşen bir olgudur. Dolayısıyla mobbing çalışma hayatında yer alan herkes için geçerlidir. Gelişmiş ülkelerde mobbing ile ilgili bireysel ve hukuksal farkındalık daha üst seviyede iken, ülkemizde henüz o seviyelere ulaşılmış değildir. Ancak toplumumuz ve hukuk sistemimiz de gün geçtikçe bu yönde iyi gelişmeler olduğu da bir gerçektir.

Mobbing kurbanlar üzerinde telafisi pek de mümkün olmayan ağır travmalar bırakmaktadır. $\mathrm{Bu}$ problemin çözümünde önemli olan kurbanın farkında olduğu kadar, işverenlerin, mesai arkadaşlarının ve sosyal çevreninde konu ile ilgili bilinçli olması gerekmektedir. Mobbingi sona erdirmek için hukuki düzenlemeler yanında bireylerin ve toplumunda iyi düzeyde bilgi sahibi olması önemlidir. Bu bağlamda mobbing olgusu ile ilgili toplumu bilinçlendirmek ve farkındalığın artır1lmas1 gerekmektedir.

Hılı bir gelişmenin ve acımasız bir rekabetin varolduğu günümüz dünyasında işletmeler açısındanmobbing önem arz eden bir sorun alanıdır. Bir işletmeyi içten yiyenmobbing gibi bir olumsuz olguyu etkisizleștirmeyi beceren, mobbing risklerini aza indirgeyen işletmeler iş yaşamı içerisinde pozitif bir ortam yaratarak, çalışanlarına kıymet vererek onları değerli hissettirmeyi odaklarına aldıklarında olumlu çıktılar elde ederken, tersi durumda çıktılar olumsuz olmaktadır. Çalışanına eşit davranan, değer veren örgüt kültürü sayesinde çalışanların işe bağımlılık düzeyi yükselmekte, yanı sıra kendilerini işletmenin bir parçası olarak görüp daha verimli çalışmaya başlayacaklardır. Başarının birkaç anahtarından biri olan çalışanın mutluğu, çalışanlar arası eşit muamele, hoşgörü, hakkaniyet ve adalet işletmeler için önemli faydalar sunmaktadır. Huzurlu toplumları, huzurlu bireyler ve iş ortamları oluşturmaktadır. Huzurun artması,mutlu insanları,mutlu insanlarda mutlu yeni nesilleri ve nihayet mutlu toplumları oluşturacaktır.

\section{KAYNAKÇA}

Atman, Ü. (2012). İşyerinde Psikolojik Terör:Mobbing. Sağlıkta Performans ve Kalite Dergisi, 3(1), s. 157-174.

Bulut, S. ve Göktürk, G . (2012). Mobbing: İşyerinde Psikolojik Taciz . Bolu Abant İzzet Baysal Üniversitesi Sosyal Bilimler Enstitüsü Dergisi , 12 (1), s.53-70.

Chappell, D. \& DiMartino, V. (1998).Violence at Work. ILO, Report ,P.2.

https://www.ilo.org/wcmsp5/groups/public/@dgreports/@dcomm/@publ/documents/publication/ wcms_publ_9221108406_en.pdf (erişim 01.09.2020).

Creswell, J. W. (2017). Araştırma Deseni Nitel,Nicel ve Karma Yöntem Yaklaşımları. Ankara: 


\section{Eğiten Kitap Yayınevi.}

Çetin, A. (2015). İş Hayatında Yıldırma'nın (Mobbing) Çalışanların Örgütsel Bağlılık Düzeylerine Etkisi. Bir Kamu Kurumuna Yönelik Araştırma , 2-2. Ankara: Türk Hava Kurumu Üniversitesi. Yayımlanmamış Yüksek Lisans Tezi.

DMK 657 Genel Hükümler. Madde 10. https://www.mevzuat.gov.tr/MevzuatMetin/1.5.657.pdf (erişim 01.09.2020).

Matthiesen, S. B., \& Einarsen, S. (2004). Psychiatric distress and symptoms of PTSD among victims of bullying at work. British journal of guidance \& counselling, 32(3), s. 335-356.

Field, T.(1996). Bully Insight. How to Pretict, Resist, Challenge and Combat Workplace Bullying. Overcoming the Silence and Danial by which Abuse Thrives, Oxfordshire: Sucsess Unlimited.

Güngör, M. (2008). Çalışma Hayatında Psikolojik Taciz. İstanbul: Derin Yayınları. İşyerinde Psikolojik Taciz (Mobbing) ve Çözüm Önerileri Komisyon Raporu. (2011). TBMM Kadın Erkek Fırsat Eşitliği Komisyonu Yayınları.

Leymann, H. (1996). "The Content of Development of Mobbing at Work“. Europen Journal of Work and Organizational Psychology . 5, s. 165-184.

Martino, D. V. (2003). "Preventing Violence and Harrassment in The Workplace". Ireland: European Foundation for the Improvement of Living and Working Conditions .

Tetik, S. (2010). "Mobbing Kavramı:Birey ve Örgütler Açısından Önemi". KMÜ Sosyal ve Ekonomik Araştırmalar Dergisi , 12 (18), s. 81-89.

Tınaz, P. ve Karatuna, I. (2010). İşyerinde Psikolojik Taciz, Sağlık Sektöründe Kesitsel Bir Araştırma, Ziraat Grup Matbaacılık A.Ş. Türk-İş.

Yücetürk, E. (2005). Türkiye'de İş Yaşam Kalitesi ve Verimliliği Azaltan Gizli Bir Sendrom: Yildırma (Mobbing). İktisat Issletme ve Finans Dergisi . 20 (231), s. 97-108.

Web 1: https://bullyonline.org/old/workbully/costs.htm\#Employer (erişim 15.09.2020). 